Piroska Hoffmann - Zoltán Baracskai

\title{
Does trust matter? The role of trust in collaboration in virtual teams*
}

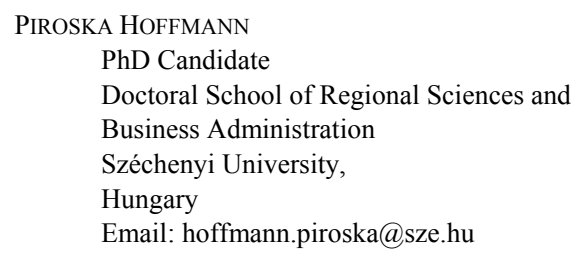

\author{
ZOLTÁN BARACSKAI \\ Professor \\ Doctoral School of Regional Sciences and \\ Business Administration \\ Széchenyi University, \\ Hungary \\ Email: baracskai.zoltan@sze.hu
}

Virtual cross-border teams emerged after the global credit crisis as a new operational phenomenon of multinational enterprises. This new form eliminates country-based entities and combines local departments. It is of notable benefit to financial efficiency; however, it may have a crucial impact on the structural dimension and nature of relations (ties) of social capital. The damage to ties is characterised by weak trust and heightened operational risk. Measuring trust directly is cumbersome; therefore, this study aims to measure its inversion (internal control). A quantitative research method is used to analyse $a$ ) the data (location, nationality, level of seniority, department) of 495 managers of a multinational enterprise to describe their impact on the structural dimension of social capital and the ties between employees, and b) 298 operational control points to find a statistical correlation among their number, the various types of risks and organisational diversity. The authors' correlation analysis demonstrates that all well-structured high-risk processes are controlled by the organisation. However, the internal controlling system does not seem to cover the trust-based ill-structured processes: human relations and behaviour.

KEYWORDS: virtual team, social capital, trust

In the last two decades, a significant change has been observed in the working environment and in the content of jobs and positions in the subsidiaries of multinational enterprises (MNEs). Several factors have contributed to this change, but the advancement of communication technologies is leading and intensifying the process

* This research has not received any specific grant from funding agencies in the public, commercial, or not-for-profit sectors.

Hungarian STATISTICAL REVIEW, VOlumE 3, NuMBER 2, PP. 50-70. DOI: 10.35618/hsr2020.02.en050 
(Berry [2011], Weimann et al. [2013], Plotnik-Hiltz-Privman [2016], Seetharaman et al. [2019]). The internet and mobile communication revolution has ensured the necessary infrastructural background (Powell-Piccoli-Ives [2004], SchulzeKrumm [2017), it has driven and supported the development of new organisational structures (Arnold-Barling-Kelloway [2001], Kauffmann-Carmi [2019]), and provided a new opportunity to exchange information (Van Den Hooff-Ridder [2004], Walther-Anderson-Pmk [1994]). In addition to face-to-face (FtF) teams, this progress has brought about the emergence of a new kind of working engagement, the remotely working virtual team (Berry [2011], Morita-Burns [2014]). The computer-mediated communication (CMC) technology is a fast-growing sector whose innovations and tools support communication, knowledge sharing and relational capital in virtual teams and manage the whole spectrum of collaboration (CoròGrandinetti [2001], Robert-Dennis-Ahuja [2008], Wei-Thurasamy-Popa [2018], Zornoza-Orengo-Peñarroja [2009]).

After the 2008-2009 global credit crisis, the development of information and communication technology (ICT) met financial pressure, which accelerated the transformation of FtF teams to virtual ones. The latter organisational form has helped MNEs reduce operational costs by eliminating country-based entities and setting up cross-border, multicultural virtual teams (Appio et al. [2017], GermainMcGuire [2014]). The transition was accelerated by the 'promise' of improving financial efficiency, decreasing (personal, equipment, and workplace) costs, and increasing access to new resources, including human capital (Horwitz-BravingtonSilvis [2006]). One form of virtual teams manifested in MNEs is set up by merging subsidiaries to minimise costs and create a cross-border virtual organisation. This organizational form is based on the merger of equal country-based business units and led by one management team. It is different from the global virtual team in which the connection between the global team and subsidiaries can be described by a hierarchy and responsibilities (Zakaria-Mohd Yusof [2018]).

\section{Literature review}

\subsection{Virtual teams in MNEs}

The successful operation of an organisation is a managerial challenge. Traditionally, organisational teams collaborate FtF. However, the development of the ICT has enabled teams to collaborate virtually, allowing them to work together and

HungaRian STATISTICAL REVIEW, VOLUME 3, NUMBER 2, PP. 50-70. DOI: 10.35618/hsr2020.02.en050 
accomplish common goals while physically fully or partially separated (BjørnNgwenyama [2009], Gibbs-Sivunen-Boyraz [2017]). The technological development has 'rewritten' and fundamentally changed collaboration.

A virtual team in the new MNE-setup means a cross-cultural organisation as it performs activity across borders, and the teams of different countries are merged into one functional entity (Anawati-Craig [2006], Collins et al. [2017]). This poses additional challenges compared with the ones created by nation-based virtual teams (Harvey-Novicevic-Garrison [2005]). The physical (geographic) distance slows down communication, reduces the frequency of interactions, increases the social distance, negatively impacts relations (Sheng-Hartmann [2019]), and results in changes in distributed teams (Hertel-Geister-Konradt [2005], Margaryan et al. [2015]). Virtual teams appoint new roles and competencies to employees. One of these new roles is played by multicultural brokers who help to overcome physical boundaries and distance, support collaboration and contribute to transferring knowledge both in terms of quantity and quality (Eisenberg-Mattarelli [2017]). Communication is a critical element of team effectiveness and efficiency (Kock-Lynn [2012]).

\subsection{Individuals in a virtual team}

Creating virtual teams is a new way to make work more productive and flexible to realise profitability (Zakaria [2017]), but these changes influence the employees of multinational companies. Flexibility is an essential feature of virtual teams; it shows their capability to adapt rapidly to fast-changing CMC tools and work processes as well as unique communication challenges (Jimenez et al. [2017], PowellPiccoli-Ives [2004], Schulze-Krumm [2017]).

Cross-border multicultural virtual teams, however, involve a high level of complexity, which may increase ambiguity and create a lack of transparency for team members. It is a real cultural shift in attitude and cooperation, which affects everyday practices and has long-term consequences. Working in a diverse team is not a new phenomenon in the modern world, but today it may refer to nationality, position or seniority in the organisation, functional specialty, or geographic location (EdeworAluko [2007]). Our research focuses on this latter definition (structural diversity).

\subsection{Social capital in a virtual team}

Social capital denotes existing and potential human resources that can only be utilised through human relations (Anheier-Gerhards-Romo [1995]). People need to rely on each other, taking advantage of their connections (Portes [1998]).

Hungarian STATISTICAL REVIEW, VOluME 3, NuMBER 2, PP. 50-70. DOI: 10.35618/hsr2020.02.en050 
Nahapiet-Goshal [1998] define three dimensions of social capital: 1. nature of relations (ties), 2. cognitive dimension, and 3. structural dimension. The first describes people's working relationships, which develop via interactions and provide a channel for information flow and knowledge sharing. The cognitive dimension specifies the vision or the collective goals of an organisation. It refers to the intellectual capital that is the universal language, codes, common paradigms, and the chance to share knowledge (Ariani [2012]). The organisational structure determines the evolution of the cognitive and relational dimensions of social capital. The structural dimension describes the social interactions originated in the organisational architecture that influences the relations among people, predicts their behaviour, and helps appear social motives such as respect, trust, and friendship (NahapietGoshal [1998], Widjaja et al. [2017], Milana-Maldaon [2015]). The cognitive dimension specifies the vision or the collective goals of an organisation. It refers to the intellectual capital that is the universal language, codes, common paradigms, and the chance to share knowledge (Ariani [2012]). Many types of capital exist as assets of the organisation, but the social capital is different. It is embedded in the community and the connections among individuals. The development of social capital in a virtual team highly depends on the willingness of individuals to connect in action.

The structure of a virtual team influences each of the above dimensions, where the social capital develops internally (Jensen-Meckling [1976], Tallman et al. [2004]). However, the development of social capital may stall across organisational and national borders (Harvey-Novicevic-Garrison [2005]). In a virtual team, members never meet FtF, and trust, the main dimension of social capital, does not develop organically (Harvey-Novicevic-Garrison [2005]).

\subsection{The role of trust in collaboration}

Trust has an essential role in building and supporting collaboration in virtual teams. Every organisation's goal is to create unity within diverse teams, while people's relations are contradictory. In leadership theories, trust is described as a leader-follower relationship or, more precisely, the way how a follower understands the nature of the relationship (Ferrin-Dirks [2002]). Building and maintaining trust in a virtual cross-cultural team is a major challenge as personal relationships can be damaged.

A large body of literature on trust focuses on personal behaviour and refers to trust in the organisation as an individual's ties that are expressed on two levels: team trust and organisational trust (Kramer [1999]). Interpersonal trust is of increasing importance; it solidifies group dynamics and effective collaboration. Numerous studies measure trust in organisation sciences. Most trust instruments are either at an

HungaRian STATISTICAL REVIEW, VOLUME 3, NUMBER 2, PP. 50-70. DOI: 10.35618/hsr2020.02.en050 
individual level, related to peers, or at a dyadic level between leaders and subordinates or between organisations (inter-organisational trust; Smith-Barclay [1997]). Most researchers regard trust as a multidimensional, complex and abstract phenomenon that involves specific components. They conceptualise trust as a multicomponent variable with the following dimensions: propensity to trust, cooperative behaviours, perceived trustworthiness, monitoring behaviours, affective commitment, team commitment, and continuance commitment (Costa-Anderson [2011]). At the interpersonal level, trust is always described as a process when the 'trustor' is trusting in another person, the trustee. Mayer-Davis-Schoorman define trust as 'the willingness of a party to be vulnerable. Trusting relationships lead to greater knowledge exchange' ([1995] p. 712.), which is the most common definition in organisational trust research (McEvily-Tortoriello [2011]). Trust creates a climate where both agents can predict the other's behaviour, reduce vagueness, and evaluate what kind of behaviour is desired in the future (Lewicki-TomlinsonGillespie [2006]). On a team level, this appears as expected behaviours and norms, and influences others' behaviour (their communication openness, acceptance of influence, support for the spirit of cooperation, and information sharing). According to the researchers, trust is a psychological state and inherently an individual-level phenomenon. Investigating trust in a virtual organisation as the product of a collective entity is, however, complicated.

Trust and trusting relationships are a central value of social capital; they have a dynamic impact on building social capital and exchanging knowledge. Trust is the central element of the willingness for collaboration, knowledge transfer, networking, smooth and non-competitive interactions, and building of social capital (StriukovaRayna [2008]). To support team collaboration, companies should realise that the nature of trust is not the same in virtual teams as in FtF teams due to their different interpersonal dynamics, and they should develop a strategy to strengthen trust (FordPiccolo-Ford [2017], Zakaria-Mohd Yusof [2018]).

\section{Organisational structure and collaboration in a virtual team}

A systematic literature review was conducted to get a comprehensive picture of the recent studies on virtual cross-border organisations, the way they approach the development of collaboration, and the role of trust in such organisations. After the exclusion of local, non-intercultural studies, a total of 46 papers from various disciplines (e.g. business and international management, organisational behaviour and human resource management $[\mathrm{HR}]$, psychology, electronic engineering and

HungARIAN StatistiCAL ReVIEW, VOluME 3, NuMBER 2, PP. 50-70. DOI: 10.35618/hsr2020.02.en050 
computer science, strategy management, finance, arts, and humanities) were selected for further analysis, providing a multidisciplinary perspective.

Our first conclusion drawn from the review is that there is no common definition of virtual teams in the articles, but the content of the various definitions is uniform: they are teams, whose members work remotely, not having face-to-face daily interactions. 'Fully virtual teams' and 'partially virtual teams' are not clearly separated in the literature, but the phenomenon is homogenous (Alsharo-Gregg-Ramirez [2017]; Ambos et al. [2016]; Bisbe-Sivabalan [2017]; Cheng et al. [2016], [2017]; NewmanFord-Marshall [2019]; Plotnik-Hiltz-Privman [2016]; RamalingamMahalingam [2018]; Vahtera et al. [2017]). Only a limited number of papers analyse the organisational structure of remote teams, and the research that explores the levels of virtuality and their effects on business processes is scant (Caya-MortensenPinsonneault [2013], Hertel-Geister-Konradt [2005]). Although the organisational structure, the structural dimension of social capital and the interaction of the different roles in FtF organisations are among the most investigated topics, only six of the selected articles deal with these subjects in terms of virtual teams. A better understanding of the structure of remote teams may help to expand our knowledge on the development of trust, and allows researchers to predict more successfully how such teams will affect team members' work and facilitate the development of intra-organisational ties. Only a small number of studies examine the potential benefits of structural diversity in virtual teams (Caya-Mortensen-Pinsonneault [2013]).

The second methodological conclusion drawn from the literature review is that the research on university student teams is overrepresented. Although student teams are an excellent 'laboratory' of collaboration measurement, students are in the early phase of socialisation (Powell-Piccoli-Ives [2004]). This is confirmed by a case when the most effective leadership style was different in the virtual teams of enterprises from that of student teams. In virtual teams, the 'strong' leadership approach was the most effective, whereas student teams preferred the 'emergent' style (GibbsSivunen-Boyraz [2017]). Thus, the application of student-team-related results for multinational enterprises requires caution and secondary research.

We have also performed a systematic analysis to identify discrepancies between the examinations of trust-based ill-structured behaviour and those of well-structured process-controlled behaviour (Guindon [1990]), in terms of collaboration in multicultural virtual teams. Each article addresses collaboration, approaching the subject through trust or the team members' personal characteristics (Choi-Cho [2019], Davison et al. [2017], Henderson-Stackman-Lindekilde [2016], Lisak-Erez [2015]). 


\section{Problem area: how to measure trust in virtual teams?}

Trust is the acceptance of the unregulated part of human behaviour and its role is to alleviate over-regulation. The main problem is related to the difficulty of measuring trust. Most of the articles use quantitative research methods for this purpose (Adya-Temple-Hepburn [2015], Choi-Revilla [2019], Collins et al. [2017], Davison et al. [2017], Hao-Yang-Shi [2019], HendersonStackman-Lindekilde [2016], Iorio-Taylor [2015], Kauffmann-Carmi [2019], Margaryan et al. [2015], Nestle et al. [2019], Paul-Drake-Liang [2016], PetterBarber-Barber [2019], Widjaja et al. [2017]). Nevertheless, all the selected quantitative articles employ a self-survey method that is based on 5- or 7-point semantic differential scales. This method has many advantages, but cannot be deemed an objective, non-opinion-based data measurement technique.

In contrast, measuring lack of trust (distrust) through the correlation between internal controls and hierarchical distance may provide an objective picture of reality. Five of the reviewed articles focus on collaboration, examining the scope of controls and processes, but only two of them investigate virtual teams in MNEs.

Many studies analyse the dimensions, factors and elements of trust in organisations, qualifying its level indirectly (Butler [1991], Ferrin-Dirks [2002], McEvilyTortoriello [2011]).

There are two types of opinions about measuring trust. Our position is closer to the one that trust cannot be measured directly, and as an alternative approach, lack of trust (distrust) should be measured through the correlation of internal controls, hierarchical distance, and cultural diversity.

To understand the problem of collaboration and trust, the main task is to divide the problem area into measurable and quantifiable parts. As measuring trust is cumbersome, we examine whether it is possible to measure the inverts of trust (regulation and control) instead. If each process of the organisation is well structured and regulated, employees' behaviour is rule-based, and their collaboration is less dependent on trust. In contrast, generating new ideas for decision making is ill-structured (Guindon [1990]); it depends on personal tribes, where trust-based behaviour is a key element.

The primary aim of our data analysis is to map the well- and ill-structured processes of an MNE and determine the number of control points built into these processes to minimise systematic and non-systematic risks. We examine whether these control points cover all the behaviour elements (every single process, including personal behaviour) or only the well-structured ones. This subject can only be examined in the light of the organisational structural changes. Analysing the internal relations and controls within various departments (functions) of an organisation is a new way to describe collaboration in multicultural virtual teams of MNEs.

HungaRian STATISTICAL REVIEW, VOLUME 3, NUMBER 2, PP. 50-70. DOI: 10.35618/hsr2020.02.en050 


\section{Methodology}

Our data were collected in May 2019 from an MNE that operates in more than 50 countries, with subsidiaries in four regions and with 13 virtual organisations. The most prominent of these virtual organisations, where our research was run, operates in North-Eastern-Europe and covers 13 countries (the organisation has offices in 9 countries and works with local distributers in 4 countries). Each department works remotely in virtual teams: the heads of the departments are in their home country offices, and the team members are in their home countries (3 to 8 locations). This structure supports the proximity to the local market, but creates considerable complexity and distance within the virtual teams at the functional level. Employees are divided into two groups: non-managers with local responsibility and managers with cross-border responsibility. As the first step, data from 495 managers (location, nationality, level of seniority, department) were analysed to gain a clear picture of the structural dimension of social capital and cultural diversity in the MNE. Then, as a second step, the company's controlling system (i.e. how the diversity and control of processes support safe operation) was examined. Furthermore, it was mapped how the company covers the well- and ill-structured processes with controls.

The company employs a risk management and prevention system, called Vestalis, for controlling, analysing, and prioritising non-systematic risks. 298 control points were introduced covering all functions, and they are grouped as 1 . basic function regulation without risk, 2. financial risk, 3. fraud risk, 4. financial and fraud risks. The system also involves two directions of actions (preventive and detective actions). The company has precise regulations to control most types of risks, which apply to the following: timeframe of reviews, type of control and documentation, and effects of controls on systematic or non-systematic risk. In this study, we analyse the 298 control points by functional and country levels. Our goal is to find a statistical correlation between the various types of risks, and compare the number of control points with the level of cultural diversity in the various functional areas (departments). The data analysis was performed with the JMP Pro 14 statistical software.

\section{Findings and discussion}

The functional variance and seniority as well as the number of nationalities confirm that this is a culturally diverse cross-border virtual organisation, and the entire team's diversity appears in all job families. The bottom of the organisation

HungaRian STATISTICAL REVIEW, VOLUME 3, NUMBER 2, PP. 50-70. DOI: 10.35618/hsr2020.02.en050 
(level of junior managers) - just like the various levels of directors - is less diverse than the managerial levels. Diversity decreases with seniority among directors, and there is no diversity at the top of the organisation. (See Figure 1.) The company approach decentralises and localises the 'Sales' department in order to maintain the proximity to the market. This functional team comprises only a few members from different levels of the organisation, but is more extensive and less centralised at the lower director level.

Figure 1. Employee classification (seniority) and the number of nationalities by management level (entire organisation and functional virtual teams)

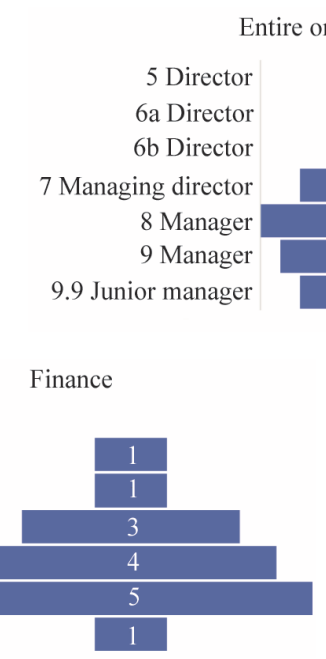

Operation

5 Director

6a Director

$6 \mathrm{~b}$ Director

7 Managing director

8 Manager

9 Manager

9.9 Junior manager

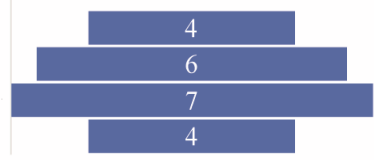

HR

5 Director

6a Director

$6 \mathrm{~b}$ Director

7 Managing director

8 Manager

9 Manager

9.9 Junior manager

$$
\text { Entire organisation }
$$
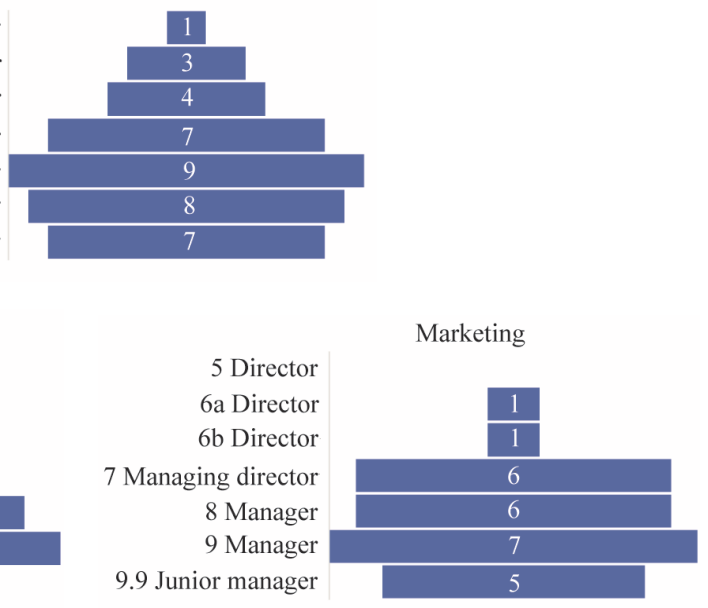

Sales

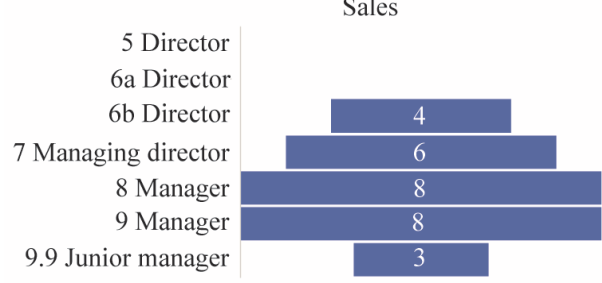

R\&D

5 Director

6 Director

6b Director

7 Managing director

8 Manager

9 Manager

9.9 Junior manager

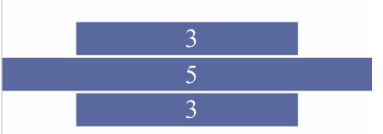

Note. R\&D: research and development. 
Table 1

\begin{tabular}{|c|c|c|c|c|}
\hline \multirow{2}{*}{ Country } & Variance & Mean & Median & \multirow{2}{*}{$\begin{array}{c}\text { Range in } \\
\text { employee } \\
\text { classification }\end{array}$} \\
\hline & \multicolumn{3}{|c|}{ of the number of employees } & \\
\hline Bulgaria & 0.80 & 8.58 & 9 & 3.9 \\
\hline Czech Republic & 0.59 & 8.43 & 9 & 2.9 \\
\hline Finland & 1.37 & 8.59 & 9 & 3.9 \\
\hline Hungary & 1.04 & 8.30 & 9 & 4.9 \\
\hline Latvia & . & 8.00 & 8 & 0.0 \\
\hline Poland & 0.85 & 8.38 & 9 & 3.9 \\
\hline Romania & 0.58 & 8.47 & 9 & 2.9 \\
\hline Slovakia & 0.25 & 8.75 & 9 & 1.0 \\
\hline Sweden & 0.84 & 8.47 & 9 & 3.9 \\
\hline
\end{tabular}

Table 2

Employee classification by department

\begin{tabular}{l|c|c|c|c|c}
\hline \multirow{2}{*}{ Department } & Variance & Mean & Median & $\begin{array}{c}\text { Range in } \\
\text { employee } \\
\text { classification }\end{array}$ \\
\cline { 2 - 5 } Finance & \multicolumn{2}{|c}{ of the number of employees } & 3.9 \\
\hline General management & 0.80 & 8.46 & 9.0 & 1,0 \\
\hline General secretary & 0.50 & 5.50 & 5.5 & 0.0 \\
\hline HR &. & 9.00 & 9.0 & 2.0 \\
\hline Industry & 0.57 & 8.00 & 8.0 & 3.9 \\
\hline IT & 0.99 & 8.37 & 9.0 & 3.0 \\
\hline Marketing & 0.63 & 8.48 & 9.0 & 3.9 \\
\hline Medical and health affairs & 1.10 & 8.34 & 8.0 & 1.0 \\
\hline Office services & 0.50 & 8.50 & 8.5 & 0.0 \\
\hline Operations &. & 9.00 & 9.0 & 3.9 \\
\hline Purchases & 0.76 & 8.55 & 9.0 & 3.0 \\
\hline Quality & 0.90 & 7.86 & 8.0 & 3.0 \\
\hline R\&D & 0.66 & 8.45 & 9.0 & 2.0 \\
\hline Sales & 0.64 & 8.06 & 8.0 & 3.9 \\
\hline & 0.74 & 8.50 & 9.0 & \\
\hline
\end{tabular}

Employee seniority is independent of nationality or location. No significant difference is observed in terms of the mean and the median among countries and departments regarding seniority. (See Tables 1 and 2.) Employee classification is

Hungarian STATISTICAL REVIEW, VOlumE 3, NuMBER 2, PP. 50-70. DOI: 10.35618/hsr2020.02.en050 
independent of the number of employees per country. (See Table 1 and online Annex for Figures A1 and A2. [http://search.ksh.hu/\#/year/2020?c=h02]) The data analysis confirms that the structural dimension of the social capital in the organisation is fundamentally different from that of the FtF-based country model, but it is balanced by and based on quality.

The results of the analysis of control points indicate that all high-risk and wellstructured processes (Finance, HR, Operation, and IT) are highly controlled. (See Figure 2.) A strong correlation was revealed between teams' diversity and the number of control points. Finance is the most controlled department, in line with the aspiration of reducing systematic and non-systematic risks.

Figure 2. Number of control points by department

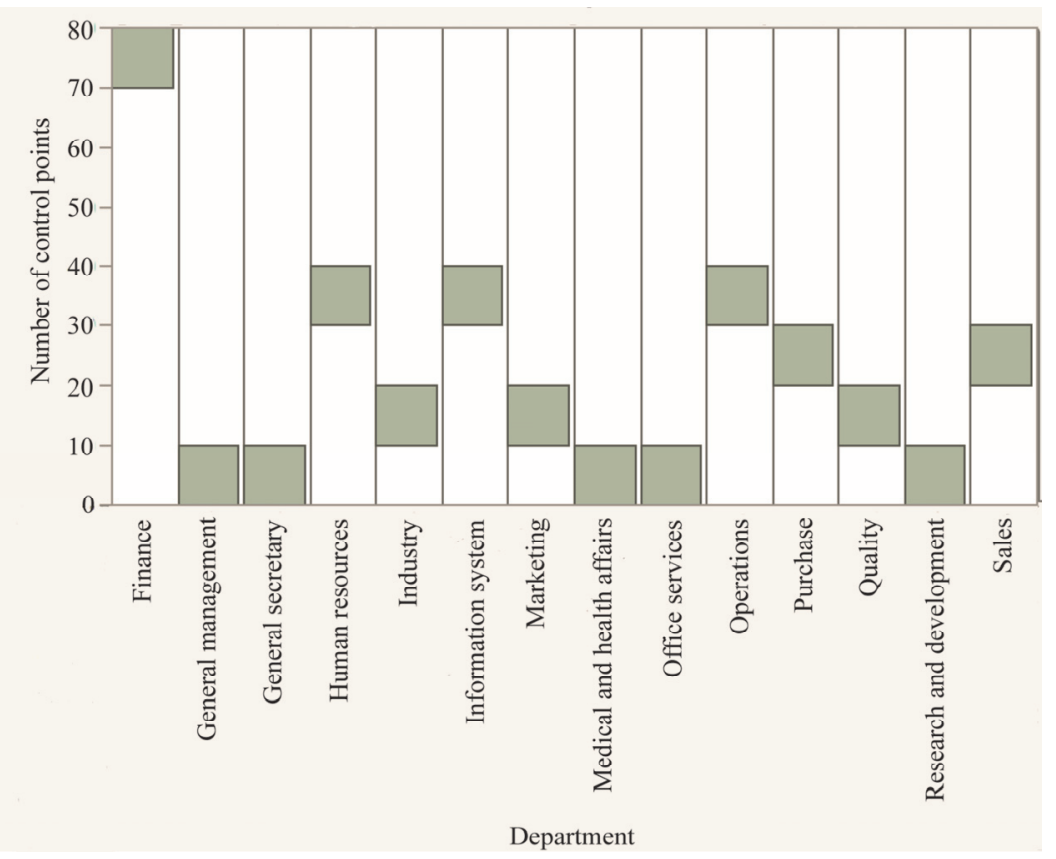

The range between the various organisational levels is an important indicator of diversity. In a well-balanced organisation, all levels of seniority are observable through the presence of a strong successor plan, which increases the organisation's retention ability. At the same time, it is one of the most significant risks for a remotely working virtual team. Our correlation analysis has revealed that the number of control points is highly correlated with the range in the employee classification (0.65; see Table 3$)$. In this way, the studied MNE can maximise the benefits of diversity while reducing the risk via internal controlling.

HungaRian STATISTICAL REVIEW, VOLUME 3, NUMBER 2, PP. 50-70. DOI: 10.35618/hsr2020.02.en050 
Based on the in-depth analyses, we found that internal controlling applies more rule-based controls to minimise financial risk in teams where the employees work at a longer distance from each other or in teams which face a potential financial or fraud risk in the course of daily operations. A strong correlation can be observed between the various types of risks (financial, fraud, and both financial and financial risks) and the two types of control (preventive and detective), weighted by the number of control points. (See Table 4 and Figure A3.)

Table 3

Correlations between employee diversity (classification)

and the number of control points in the business processes

\begin{tabular}{|c|c|c|c|c|c|c|}
\hline \multirow{2}{*}{\multicolumn{2}{|c|}{ Denomination }} & $\begin{array}{c}\text { Geometric } \\
\text { mean }\end{array}$ & Median & Mean & \multirow{3}{*}{$\begin{array}{c}\text { Range in } \\
\text { employee } \\
\text { classification }\end{array}$} & \multirow{3}{*}{$\begin{array}{c}\begin{array}{c}\text { Number of } \\
\text { control points }\end{array} \\
0.17 \\
\end{array}$} \\
\hline & & of th & mber of $\mathrm{e}$ & & & \\
\hline Geometric mean & \multirow{3}{*}{$\begin{array}{l}\text { of the number of } \\
\text { employees }\end{array}$} & 1.00 & 0.94 & 1.00 & & \\
\hline Median & & 0.94 & 1.00 & 0.94 & 0.26 & 0.33 \\
\hline Mean & & 1.00 & 0.10 & 1.00 & 0.10 & 0.18 \\
\hline \multicolumn{2}{|c|}{ Range in employee classification } & 0.08 & 0.26 & 0.10 & 1.00 & 0.65 \\
\hline \multicolumn{2}{|c|}{ Number of control points } & 0.17 & 0.33 & 0.18 & 0.65 & 1.00 \\
\hline
\end{tabular}

Note. The correlations were estimated by the Row-wise method.

Table 4

Correlations between the three types of risks and the two types of control, weighted by the number of control points in the business processes

\begin{tabular}{l|c|c|c|c|c|c}
\hline \multicolumn{1}{c|}{ Denomination } & Risk & Financial risk & Fraud risk & $\begin{array}{c}\text { Financial and } \\
\text { fraud risks }\end{array}$ & $\begin{array}{c}\text { Preventive } \\
\text { control }\end{array}$ & $\begin{array}{c}\text { Detective } \\
\text { control }\end{array}$ \\
\hline Risk & 1.00 & 0.98 & 1.00 & 0.96 & 0.92 & 0.97 \\
\hline Financial risk & 0.98 & 1.00 & 0.96 & 0.98 & 0.96 & 0.98 \\
\hline Fraud risk & 1.00 & 0.96 & 1.00 & 0.96 & 0.91 & 0.96 \\
\hline Financial and fraud risks & 0.96 & 0.98 & 0.96 & 1.00 & 0.95 & 0.97 \\
\hline Preventive control & 0.92 & 0.96 & 0.91 & 0.95 & 1.00 & 0.89 \\
\hline Detective control & 0.97 & 0.98 & 0.96 & 0.97 & 0.89 & 1.00 \\
\hline
\end{tabular}

The MNE has grouped the control points into the following five main categories: 1. supporting the enterprise, 2. managing sourcing, 3. managing sales, 
4. generating demands, and 5. forecasting stock. Almost half (47\%) of the control points fall into the category of 'supporting the enterprise'. A good example of this category's relative majority is HR (that is among the most controlled functions and has well-structured processes) whose every control point serves this purpose, just like the control points of the IT and legal affairs departments. Nevertheless, if we examine the whole scope of HR activities, only a small part of such activities can be linked to the category of 'supporting the enterprise', which - being well-structured processes - are measurable and controllable. Our analysis has revealed a massive gap between these well-structured processes and the other part of HR activities, as the latter, ill-structured content of the HR function is not controlled.

Table 5

\begin{tabular}{|c|c|c|c|c|c|c|}
\hline Department & $\begin{array}{l}\text { Forecasting } \\
\text { stock }\end{array}$ & $\begin{array}{c}\text { Generating } \\
\text { demand }\end{array}$ & $\begin{array}{l}\text { Managing } \\
\text { sales }\end{array}$ & $\begin{array}{c}\text { Managing } \\
\text { sourcing }\end{array}$ & $\begin{array}{c}\text { Supporting } \\
\text { the enterprise }\end{array}$ & Total \\
\hline Finance & 2 & & 5 & 13 & 51 & 71 \\
\hline $\mathrm{HR}$ & & & & & 30 & 30 \\
\hline IT & & & & & 34 & 34 \\
\hline Legal affairs & & & & & 4 & 4 \\
\hline Manufacturing & 10 & & & & 4 & 14 \\
\hline Marketing & & 12 & & 1 & 1 & 14 \\
\hline Medical affairs & & 1 & & & & 1 \\
\hline Quality & 2 & 2 & & 1 & 8 & 13 \\
\hline $\mathrm{R} \& \mathrm{D}$ & & 8 & & 1 & & 9 \\
\hline Sales & & & 25 & & & 25 \\
\hline $\begin{array}{l}\text { Sourcing and supplier } \\
\text { development }\end{array}$ & & 1 & 2 & 22 & 2 & 27 \\
\hline Supply chain & 25 & & 19 & 5 & 7 & 56 \\
\hline Total & 39 & 24 & 51 & 43 & 141 & 298 \\
\hline
\end{tabular}

Note. The table does not contain all departments of the enterprise.

In contrast to the well-structured high-risk processes, ill-structured soft processes (managers' behaviour and collaboration), where personal relations play an important role, are not regulated by the organisation, and the lack of control may make the organisation vulnerable. 


\section{Conclusion}

Setting up multicultural virtual teams in MNEs is an emerging phenomenon; thus, the structure of these teams has been less studied so far than that of classic FtF organisations. The activity of virtual teams in MNEs can be considered as crossborder collaborations of cross-cultural functional teams where both leaders and their followers (peers) work in different offices, affecting the development of ties and trust in the organisation. Several studies have explored a similar phenomenon among university students. Although teams of students are easier to access than those of employees in MNEs, their 'relationship' with digital tools is different and thus challenge comparability. In addition, the socialisation phase of student virtual teams makes the applicability of such results questionable.

We have reviewed several quantitative studies and selected 46 of them for further analysis. In all the selected studies, a self-evaluation method was used to investigate the various elements of trust as its direct measurement is difficult or impossible. Development of trust, however, differs in virtual and FtF teams due to their dissimilar interpersonal ties, and the role of trust may be crucial in virtual teams.

We agree with those scholars who claim that direct measurement of trust is impossible. Therefore, we have measured the inversion of trust, (i.e. lack of trust) and converted it into a quantitative indicator (number of control points). It was found that the internal controls of the studied MNE could not regulate both dimensions of behaviour (well-structured processes and ill-structured behaviour).

The MNE has established several control points to minimize operational risk. The bottom of its organisation is 'narrow', only a limited number of junior employees work in the virtual teams, and a high level of cultural diversity can be observed among managers and senior managers. Team seniority is a useful indicator that shows an organisation's efforts to employ experienced, competent, mature people, who can work independently. In a remote collaboration, risk consciousness is indispensable on a personal level, and more significant than in an FtF team where the leader is present every day and can monitor junior team members.

In the studied organisation, seniority is independent of the nationality or location of employees. This may significantly contribute to the employees' openness and equal opportunities, and the acceptance of leaders, which are the building blocks of trust. However, non-equal opportunities or a nation's objective to reach a better position would destroy all personal efforts to build interpersonal trust.

It is hard to define, specify, measure and maintain collaboration in an organisation, especially when the structural dimension of social capital and the nature of relations changed. It is particularly critical to multinational virtual teams of MNEs whose members work together from different geographic locations.

HungaRian STATISTICAL REVIEW, VOLUME 3, NUMBER 2, PP. 50-70. DOI: 10.35618/hsr2020.02.en050 
Cultural diversity supports learning from one another, which is blocked if there is no interpersonal or organisational trust in the MNE.

Extensive and comprehensive internal controlling and audits are fundamental in a company's risk management. According to our data analysis, the studied MNE follows a conscious and systematic risk prevention approach that controls wellstructured tasks. However, it is not able to regulate the quality of personal collaboration. In a virtual environment, trust has a significant role in building and supporting collaboration since there is greater interdependence among team members, which is made even difficult by cultural differences, physical distance, language difficulties, lack of non-verbal communication, and technical barriers. The ability and willingness to build and maintain trust is the 'interplay' among co-workers.

In terms of organisational cooperation, inclusive diversity is a must. Every organisation's goal is to create unity in diverse teams where team members' relations may be contradictory and pose several challenges. Nevertheless, the questions about knowledge management and collaboration in multicultural virtual teams cannot be answered by only one discipline. These teams have an influence on people's behaviour that may be the subject of future transdisciplinary research.

The scarcity of research on MNEs' virtual teams has motivated us to analyse and measure the correlation between trust and the number of control points in an MNE's business processes. Our results may help companies to examine their wellstructured processes and internal control system to minimise operational risk. The literature undervalues the impact of remote working on the development of social capital, although this threatens the collaboration in virtual teams. Based on our data, trust is strongly linked to ill-structured processes, and not replaceable by control. Due to the changes in the structural dimension of social capital, building of trust is more difficult today than it was earlier. Further research should address this subject as well as the introduction of control systems in new virtual teams to evaluate if trust and control systems are able to strengthen each other.

The research on virtual teams of MNEs is limited and does not provide a conceptual model for reinforcing trustworthy behaviour. Trust means accepting the unregulated part of human behaviour, and has an important role in alleviating over-regulation. Further research is required to confirm the findings of previous studies on interpersonal trust for this organisational form, and to create new models.

\section{References}

Adya, M. - Temple, B. K. - Hepburn, D. M. [2015]: Distant yet near: Promoting interdisciplinary learning in significantly diverse teams through socially responsible projects. Decision Sciences Journal of Innovative Education. Vol. 13. Issue 2. pp. 121-149. https://doi.org/10.1111/dsji.12058 
Alsharo, M. - GregG, D. - RAmirez, R. [2017]: Virtual team effectiveness: The role of knowledge sharing and trust. Information \& Management. Vol. 54. Issue 4. pp. 479-490. https://doi.org/10.1016/j.im.2016.10.005

Ambos, T. C. - Ambos, B. - Eich, K. J. - PuCK, J. [2016]: Imbalance and isolation: How team configurations affect global knowledge sharing. Journal of International Management. Vol. 22. Issue 4. pp. 316-332. https://doi.org/10.1016/j.intman.2016.03.005

ANAwATI, D. - CRAig, A. [2006]: Behavioral adaptation within cross-cultural virtual teams. IEEE Transactions of Professional Communication. Vol. 49. No. 1. pp. 44-56. https://doi.org/10.1109/TPC.2006.870459

AnHeier, H. K. - Gerhards, J. - Romo, F. P. [1995]: Forms of capital and social structure in cultural fields: Examining Bourdieu's social topography. Americal Journal of Sociology. Vol. 100. No. 4. pp. 859-903. https://doi.org/10.1086/230603

Appio, F. P. - Martini, A. - MASSA, S. - TestA, S. [2017]: Collaborative network of firms: Antecedents and state-of-the-art properties. International Journal of Production Research. Vol. 55. Issue 7. pp. 2121-2134. https://doi.org/10.1080/00207543.2016.1262083

ARIANI, D. W. [2012]: The relationship between social capital, organizational citizenship behaviors, and individual performance: An empirical study from banking industry in Indonesia. Journal of Management Research. Vol. 4. No. 2. pp. 226-241. https://doi.org/ 10.5296/jmr.v4i2.1483

ARnold, K. - BARling, J. - Kelloway, E. K. [2001]: Transformational leadership or the iron cage: Which predicts trust, commitment and team efficacy? Leadership \& Organization Development Journal. Vol. 22. No. 7. pp. 315-320. https://doi.org/10.1108/ EUM0000000006162

BERRY, G. R. [2011]: Enhancing effectiveness on virtual teams: Understanding why traditional team skills are insufficient. International Journal of Business Communication. Vol. 48. Issue 2. pp. 186-206. https://doi.org/10.1177/0021943610397270

Bisbe, J. - Sivabalan, P. [2017]: Management control and trust in virtual settings: A case study of a virtual new product development team. Management Accounting Research. Vol. 37. December. pp. 12-29. https://doi.org/10.1016/j.mar.2017.02.001

BJøRn, P. - NGWEnYAMA, O. [2009]: Virtual team collaboration: Building shared meaning, resolving breakdowns and creating translucence. Information Systems Journal. Vol. 19. Issue 3. pp. 227-253. https://doi.org/10.1111/j.1365-2575.2007.00281.x

ButLeR, J. K. J. [1991]: Toward understanding and measuring conditions of trust: Evolution of a conditions of trust inventory. Journal of Management. Vol. 17. No. 3. pp. 643-663. https://doi.org/10.1177/014920639101700307

CAya, O. - Mortensen, M. - Pinsonneault, A. [2013]: Virtual teams demystified: An integrative framework for understanding virtual teams. International Journal of e-Collaboration. Vol. 9. No. 2. pp. 1-33. https://doi.org/10.4018/jec.2013040101

Cheng, X. - Fu, S. - HAN, Y. - ZARIFIS, A. [2017]: Investigating the individual trust and school performance in semi-virtual collaboration groups. Information Technology \& People. Vol. 30. Issue 3. pp. 691-707. https://doi.org/10.1108/ITP-01-2016-0024

Cheng, X. - Yin, G. - AzAdegan, A. - Kolfschoten, G. [2016]: Trust evolvement in hybrid team collaboration: A longitudinal case study. Group Decision and Negotiation. Vol. 25. May. pp. 267-288. https://doi.org/10.1007/s10726-015-9442-x

Hungarian STATISTICAL REVIEW, VOLUME 3, NuMBER 2, PP. 50-70. DOI: 10.35618/hsr2020.02.en050 
CHOI, O. К. - Сно, Е. [2019]: The mechanism of trust affecting collaboration in virtual teams and the moderating roles of the culture of autonomy and task complexity. Computers in Human Behavior. Vol. 91. February. pp. 305-315. https://doi.org/10.1016/j.chb.2018.09.032

ChOI, T. Y. - ReviLla, E. [2019]: Revisiting interorganizational trust: Is more always better or could more be worse? Journal of Management. Vol. 45. Issue 2. pp. 752-785. https://doi.org/10.1177/0149206316680031

Collins, N. - Chou, Y. M. - Warner, M. - Rowley, C. [2017]: Human factors in East Asian virtual teamwork: A comparative study of Indonesia, Taiwan and Vietnam. International Journal of Human Resource Management. Vol. 28. Issue 10. pp. 1475-1498. https://doi.org/10.1080/09585192.2015.1089064

CORÒ, G. - GRANDINETTI, R. [2001]: Industrial district responses to the network economy: Vertical integration versus pluralist global exploration. Human Systems Management. Vol. 20. No. 3. pp. 189-199.

Costa, A. C. - Anderson, N. [2011]: Measuring trust in teams: Development and validation of a multifaceted measure of formative and reflective indicators of team trust. European Journal of Work and Organizational Psychology. Vol. 20. No. 1. pp. 119-154. https://doi.org/10.1080/135943[2090327[2083

Davison, R. M. - Panteli, N. - Hardin, A. M. - Fuller, M. A. [2017]: Establishing effective global virtual student teams. IEEE Transactions of Professional Communication. Vol. 60. Issue 3. pp. 317-329. https://doi.org/10.1109/TPC.2017.2702038

Eisenberg, J. - Mattarelli, E. [2017]: Building bridges in global virtual teams: The role of multicultural brokers in overcoming the negative effects of identity threats on knowledge sharing across subgroups. Journal of International Management. Vol. 23. No. 4. pp. 399-411. https://doi.org/10.1016/j.intman.2016.11.007

Edewor, P. A. - AluKo, Y. A. [2007]: Diversity management, challenges and opportunities in multicultural organizations. International Journal of Diversity in Organisations. Vol. 5. No. 6. pp. 189-196. https://doi.org/10.18848/1447-9532/CGP/v06i06/39285

FERRIN, D. L. - DiRKS, K. T. [2002]: Trust in leadership: Meta-analytic findings and implications for research and practice. Journal of Applied Psychology. Vol. 87. No. 4. pp. 611-628. https://doi.org/10.1037//0021-9010.87.4.611

FORD, R. C. - PICCOLO, R. F. - FORD, L. R. [2017]: Strategies for building effective virtual teams: Trust is key. Business Horizons. Vol. 60. Issue 1. pp. 25-34. https://doi.org/ 10.1016/j.bushor.2016.08.009

Germain, M. L. - MCGuire, D. [2014]: The role of swift trust in virtual teams and implications for human resource development. Advances in Developing Human Resources. Vol. 16. Issue 3. pp. 356-370. https://doi.org/10.1177/1523422314532097

GiBBS, J. L. - SivUnEN, A. - BoyrAZ, M. [2017]: Investigating the impacts of team type and design on virtual team processes. Human Resource Management Review. Vol. 27. Issue 4. pp. 590-603. https://doi.org/10.1016/j.hrmr.2016.12.006

Guindon, R. [1990]: Designing the design process: Exploiting opportunistic thoughts. Human-Computer Interaction. Vol. 5. Nos. 2-3. pp. 305-344. https://doi.org/10.1080/ 07370024.1990.9667157

HungaRian STATISTICAL REVIEW, VOLUME 3, NuMBER 2, PP. 50-70. DOI: 10.35618/hsr2020.02.en050 
HAO, Q. - YANG, W. - SHI, Y. [2019]: Characterizing the relationship between conscientiousness and knowledge sharing behavior in virtual teams: An interactionist approach. Computers in Human Behavior. Vol. 91. February. pp. 42-51. https://doi.org/10.1016/j.chb.2018.09.035

HARveY, M. - Novicevic, M. M. - GARRISON, G. [2005]: Global virtual teams: A human resource capital architecture. International Journal of Human Resource Management. Vol. 16. Issue 9. pp. 1583-1599. https://doi.org/10.1080/09585190500239119

HENDERSOn, L. S. - StACKMAN, R. W. - LindEKILDE, R. [2016]: The centrality of communication norm alignment, role clarity, and trust in global project teams. International Journal of Project Management. Vol. 34. Issue 8. pp. 1717-1730. https://doi.org/10.1016/ j.ijproman.2016.09.012

Hertel, G. - Geister, S. - KonRadt, U. [2005]: Managing virtual teams: A review of current empirical research. Human Resource Management Review. Vol. 15. No. 1. pp. 69-95. https://doi.org/10.1016/j.hrmr.2005.01.002

Horwitz, F. M. - Bravington, D. - Silvis, U. [2006]: The promise of virtual teams: Identifying key factors in effectiveness and failure. Journal of European Industrial Training. Vol. 30. Issue 6. pp. 472-494. https://doi.org/10.1108/03090590610688843

IORIO, J. - TAYLOR, J. E. [2015]: Precursors to engaged leaders in virtual project teams. International Journal of Project Management. Vol. 33. Issue 2. pp. 395-405. https://doi.org/10.1016/j.ijproman.2014.06.007

Jensen, M. C. - Meckling, W. H. [1976]: Theory of the firm: Managerial behavior, agency costs and ownership structure. Journal of Financial Economics. Vol. 3. Issue 4. pp. 305-360. https://doi.org/10.1016/0304-405X(76)90026-X

Jimenez, A. - Boehe, D. M. - TARAS, V. - CAPRAR, D. V. [2017]: Working across boundaries: Current and future perspectives on global virtual teams. Journal of International Management. Vol. 23. Issue 4. pp. 341-349. https://doi.org/10.1016/j.intman.2017.05.001

KAUfFMANN, D. - CARMI, G. [2019]: A comparative study of temporary and ongoing teams on e-environment. IEEE Transactions of Professional Communication. Vol. 62. Issue 2. pp. 148-164. https://doi.org/10.1109/TPC.2019.2900909

Kock, N. - LynN, G. S. [2012]: Research article electronic media variety and virtual team performance: The mediating role of task complexity coping mechanisms. IEEE Transactions of Professional Communication. Vol. 55. Issue 4. pp. 325-344. https://doi.org/10.1109/TPC.2012.2208393

KRAMER, R. M. [1999]: Trust and distrust in organizations: Emerging perspectives, enduring questions. Annual Review of Psychology. Vol. 50. February. pp. 569-598. https://doi.org/ 10.1146/annurev.psych.50.1.569

Lewicki, R. J. - Tomlinson, E. C. - Gillespie, N. [2006]: Models of interpersonal trust development: Theoretical approaches, empirical evidence, and future directions. Journal of Management. Vol. 32. Issue 6. pp. 991-1022. https://doi.org/10.1177/0149206306294405

LISAK, A. - EREZ, M. [2015]: Leadership emergence in multicultural teams: The power of global characteristics. Journal of World Business. Vol. 50. Issue 1. pp. 3-14. https://doi.org/ 10.1016/j.jwb.2014.01.002

Margaryan, A. - Boursinou, E. - LukiC, D. - De Zwart, H. [2015]: Narrating your work: An approach to supporting knowledge sharing in virtual teams. Knowledge Management Research \& Practice. Vol. 13. Issue 4. pp. 391-400. https://doi.org/10.1057/kmrp.2013.58

HUNGARIAN STATISTICAL REVIEW, VOLUME 3, NUMBER 2, PP. 50-70. DOI: 10.35618/hsr2020.02.en050 
MARRA, A. - MAZzocchitTi, M. - SARRA, A. [2018]: Knowledge sharing and scientific cooperation in the design of research-based policies: The case of the circular economy. Journal of Cleaner Production. Vol. 194. 1 September. pp. 800-812. https://doi.org/10.1016/ j.jclepro.2018.05.164

MAYER, R. C. - DAVIS, J. H. - SCHOORMAN, D. F. [1995]: An integrative model of organizational trust. Academy of Management Review. Vol. 20. No. 3. pp. 709-734. https://doi.org/ $10.2307 / 258792$

MCEvily, B. - TORTORIELlo, M. [2011]: Measuring trust in organisational research: Review and recommendations. Journal of Trust Research. Vol. 1. No. 1. pp. 23-63. https://doi.org/ 10.1080/21515581.2011.552424

MilanA, E. - MALdAON, I. [2015]: Social capital: A comprehensive overview at organizational context. Periodica Polytechnica Social and Management Science. Vol. 23. No. 2. pp. 133-141. https://doi.org/10.3311/PPso.7763

MoritA, P. P. - Burns, C. M. [2014]: Trust tokens in team development. Team Performance Management. Vol. 20. Nos. 1-2. pp. 39-64. https://doi.org/10.1108/TPM-03-2013-0006

NAHAPIET, J. - GoSHAL, S. [1998]: Creating organizational capital through intellectual and social capital. Academy of Management Review. Vol. 23. No. 2. pp. 242-266. https://doi.org/ $10.2307 / 259373$

Nestle, V. - TÄube, F. A. - Heidenreich, S. - Bogers, M. [2019]: Establishing open innovation culture in cluster initiatives: The role of trust and information asymmetry. Technological Forecasting and Social Change. Vol. 146. September. pp. 563-572. https://doi.org/ 10.1016/j.techfore.2018.06.022

Newman, S. A. - Ford, R. C. - Marshall, G. W. [2019]: Virtual team leader communication: Employee perception and organizational reality. International Journal of Business Communication. Vol. 57. Issue 4. pp. 452-473. https://doi.org/10.1177/2329488419829895

PAUL, R. - DRAKE, J. R. - LiAng, H. [2016]: Global virtual team performance: The effect of coordination effectiveness, trust, and team cohesion. IEEE Transactions of Professional Communication. Vol. 59. Issue 3. pp. 186-202. https://doi.org/10.1109/TPC.2016.2583319

Petter, S. - BArber, C. S. - BARBer, D. [2019]: Gaming the system: The effects of social capital as a resource for virtual team members. Information \& Management. Vol. 57. Issue 6. No. 103239. https://doi.org/10.1016/j.im.2019.103239

PlotNiK, L. - Hiltz, S. R. - Privman, R. [2016]: Ingroup dynamics and perceived effectiveness of partially. IEEE Transactions of Professional Communication. Vol. 59. Issue 3. pp. 203-229. https://doi.org/10.1109/TPC.2016.2583258

Porter, M. - Ketels, C. [2013]: Clusters and industrial districts: Common roots, different perspectives. In: Becattini, G. - Bellandi, M. - De Propis, L. (eds.): A Handbook of Industrial Districts. Edward Elgar Publishing. Cheltenham. pp. 172-186. https://doi.org/ 10.4337/9781781007808.00024

PORTES, A. [1998]: Social capital: Its origins and applications in modern sociology. Annual Review of Sociology. Vol. 24. pp. 1-24. https://doi.org/10.1146/annurev.soc.24.1.1

Powell, A. - Piccoli, G. - Ives, B. [2004]: Virtual teams: A review of current literature and directions for future research. ACM SIGMIS Database: The DATABASE for Advances in Information Systems. Vol. 35. No. 1. pp. 6-36. https://doi.org/10.1145/968464.968467

Hungarian STATISTICAL REVIEW, VOLUME 3, NuMBER 2, PP. 50-70. DOI: 10.35618/hsr2020.02.en050 
Ramalingam, S. - Mahalingam, A. [2018]: Knowledge coordination in transnational engineering projects: A practice-based study. Construction Management and Economics. Vol. 36. Issue 12. pp. 700-715. https://doi.org/10.1080/01446193.2018.1498591

Robert, L. P. - Dennis, A. R. - AhujA, M. K. [2008]: Social capital and knowledge integration in digitally enabled teams. Information Systems Research. Vol. 19. No. 3. pp. 314-334. https://doi.org/10.1287/isre.1080.0177

Schulze, J. - KRUMM, S. [2017]: The 'virtual team player': A review and initial model of knowledge, skills, abilities, and other characteristics for virtual collaboration. Organizational Psychology Review. Vol. 7. Issue 1. pp. 66-95. https://doi.org/ 10.1177/2041386616675522

Seetharaman, A. - Saravanan, A. S. - Patwa, N. - Niranjan, I. - Jadhav, V. PORKODI, V. P. [2019]: Impact of knowledge sharing on virtual team projects. International Journal of Knowledge Management Studies. Vol. 10. No. 4. pp. 337-364. https://doi.org/ 10.1504/IJKMS.2019.103354

SHENG, M. L. - HARTMANN, N. N. [2019]: Impact of subsidiaries' cross-border knowledge tacitness shared and social capital on MNCs' explorative and exploitative innovation capability. Journal of International Management. Vol. 25. Issue 4. No. 100705. https://doi.org/10.1016/j.intman.2019.100705

Smith, J. B. - BARCLAY, D. W. 1997]: Effects of organizational differences and trust on the effectiveness of selling partner relationships. Journal of Marketing. Vol. 61. No. 1. pp. 3-21. https://doi.org/10.2307/1252186

STRIUKOVA, L. - RAYNA, T. [2008]: The role of social capital in virtual teams and organisations: Corporate value creation. International Journal of Networking and Virtual Organisations. Vol. 5. No. 1. pp. 103-119. https://doi.org/10.1504/IJNVO.2008.016005

Tallman, S. - Jenkins, M. - HenRy, N. - Pinch, S. [2004]: Knowledge, clusters, and competitive advantage. Academy of Management Review. Vol. 29. No. 2. pp. 258-271. https://doi.org/10.5465/AMR.2004.12736089

VAhtera, P. - Buckley, P. J. - Aliyev, M. - ClegG, J. - Cross, A. R. [2017]: Influence of social identity on negative perceptions in global virtual teams. Journal of International Management. Vol. 23. Issue 4. pp. 367-381. https://doi.org/10.1016/j.intman.2017.04.002

VAN DEN HoOfF, B. - RIDDER, J. A. [2004]: Knowledge sharing in context: The influence of organizational commitment, communication climate and CMC use on knowledge sharing. Journal of Knowledge Management. Vol. 8. No. 6. pp. 117-130. https://doi.org/ $10.1108 / 13673270410567675$

WALThER, J. B. - ANDERSON, J. F. - PMK, D. W. [1994]: Interpersonal effects in computer-mediated interaction: A meta-analysis of social and antisocial communication. Communication Research. Vol. 21. No. 4. pp. 460-487. https://doi.org/10.1177\%2F009365094021004002

Wei, L. H. - Thurasamy, R. - PopA, S. [2018]: Managing virtual teams for open innovation in global business services industry. Management Decision. Vol. 56. Issue 6. pp. 570-590. https://doi.org/10.1108/MD-08-2017-0766

Weimann, P. - Pollock, M. - Scott, E. - Brown, I. [2013]: Enhancing team performance through tool use : How critical technology-related issues influence the performance of virtual project teams. IEEE Transactions of Professional Communication. Vol. 56. No. 4. pp. 332-353. https://doi.org/10.1109/TPC.2013.2287571 
WidjAJA, A. E. - Chen, J. V. - HA, Q. A. - Lin, B. [2017]: Knowledge sharing in open source mobile applications project. International Journal of Mobile Communications. Vol. 15. No. 3. pp. 306-328. https://doi.org/10.1504/IJMC.2017.083464

ZAKARIA, N. - MOHD YusOF, S. A. [2018]: Crossing cultural boundaries using the internet: Toward building a model of swift trust formation in global virtual teams. Journal of International Management. Vol. 26. Issue 1. pp. 1-19. https://doi.org/10.1016/j.intman.2018.10.004

ZAKARIA, N. [2017]: Emergent patterns of switching behaviors and intercultural communication styles of global virtual teams during distributed decision making. Journal of International Management. Vol. 23. Issue 4. pp. 350-366. https://doi.org/10.1016/j.intman.2016.09.002

Zornoza, A. - Orengo, V. - PeñArrojA, V. [2009]: Relational capital in virtual teams: The role played by trust. Social Science Information. Vol. 48. Issue 2. pp. 257-281. https://doi.org/10.1177/0539018409102414

HungaRian STATISTICAL REVIEW, VOLUME 3, NUMBER 2, PP. 50-70. DOI: 10.35618/hsr2020.02.en050 